\title{
Analysis of SME's Industry Influence on Economic Growth in Indonesia
}

\author{
Diwayana Putri Nasution \\ Universitas Pembangunan Panca Budi, Medan, Indonesia \\ diwayanaputrinst@gmail.com
}

\begin{abstract}
The research was titled "The Role of SME industry to economic growth in Indonesia. The purpose of this research is to determine the extent to which the role of the SME industry affects Indonesia's economic growth. This study saw the influence of independent variables i.e. the number of SME units, manpower, investments, and export of SMEs (intervening variables) on dependent variables of the GDP value in Indonesia. This research hypothesis shows that business units, labor, investments, and exports of SMEs have a positive and significant influence on the economic growth in Indonesia. This type of research is quantitative descriptive research using secondary data. The secondary data used comes from the statistics central Agency data. The method of data analysis used is Path Analysis in estimating the results of his research. In testing the suitability of the model, a classic assumption test is used that is the test of normality and multicollinearity test. The purpose of this research is to analyze the influence of the number of SMEs, the influence of the number of SME workers, investment influence and the influence of export from the SME sector to the Indonesian economy. From the results of the research known that the variable SME units, the number of SME workers, investment and export of SMEs as intervening variables affect the variable GDP. Overall the SME sector can affect Indonesia's economic development.
\end{abstract}

Keywords: Economic growth, SME unit, Labour, investment, SME exports Indonesia.

\section{Introduction}

Slow economic growth is not only due to weakness in the monetary and financial sector alone but also in the strong economic sector structure in the face of the turmoil from the outside of the turmoil from the inside. Before the crisis priorities, the government-industry prioritized to put the upstream industry first but ignored the downstream industry. There is a kind of statement that if the upstream industry awakens then downstream industry will follow. But in reality, the government ignored the concept of building downstream industries that can be implemented. Meanwhile, the large industries that woke up remained prone to the outside turmoil have no strong linkage in the provision of inputs. The delay of being promoted by SMEs in the program to build downstream industry and government administration towards large business development resulted in a prominent role in big business. With the slow to be promoted downstream industries occur quite badly when the Asian crisis struck the economy. In the event of a crisis, large industries have a serious problem, whereas SMEs work according to the rhythm of their respective advantages. Two patterns of industrial growth differ because of the use of raw material sourced from domestic, low wage labor and relatively fast-moving 
towards adjustment of raw materials and market-oriented. All three factors above put SMEs are able to show themselves into a business that has advantages of competitiveness and economic growth. Experts see reality and argue that the process of economic recovery is supported by significantly increasing the role of SMEs. This shows that in addition to being a crisis antidote also has a very strategic role in the economy of a country.

Table 1. Indonesia's SME Data in 2013-2016

\begin{tabular}{lcrrr}
\hline \multicolumn{1}{c}{ Tahun } & $\mathbf{2 0 1 3}$ & $\mathbf{2 0 1 4}$ & $\mathbf{2 0 1 5}$ & \multicolumn{1}{c}{$\mathbf{2 0 1 6}$} \\
\hline PDB (Billion IDR) & $5,440,007.90$ & $10,569,705.30$ & $11,531,716.90$ & $12,406,809.80$ \\
Total UKM (Unit) & 57.895 .721 & 58.444 .657 & 59.262 .772 & 59.890 .487 \\
$\begin{array}{l}\text { Total HR UKM } \\
\text { (persons) }\end{array}$ & 114.144 .082 & 119.050 .288 & 132.379 .684 & 134.632 .315 \\
Invest (Billion IDR) & $1.655 .233,5$ & $1.688 .338,2$ & 1.722 .105 & $1.761 .816,7$ \\
Export (Billion US\$) & $182.112,70$ & $185.833,49$ & $192.573,60$ & $199.313,57$ \\
\hline
\end{tabular}

From the above data can be found that SMEs are one of the sectors capable of contributing to GDP so as to increase the country's economy. With the research data, the Government should be able to provide support for SMEs to continue to improve its products so that the country's economy continues to improve. Below is a diagram that shows the change of data on the number of SMEs units and the number of SME workers as follows:

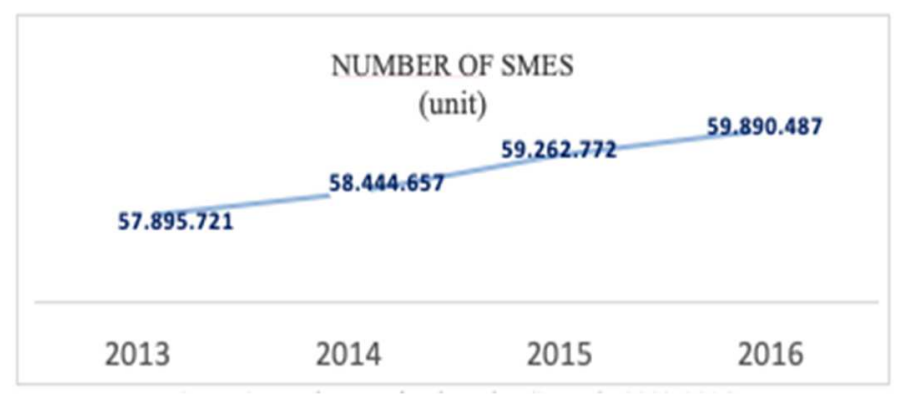

Fig 1. Total Data of Indonesian SMEs in 2013-2016

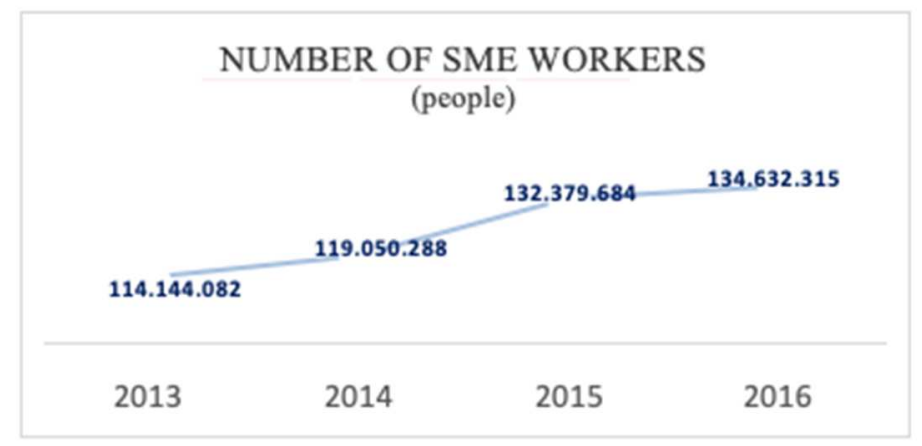

Fig 2. Data on number of Indonesian SME workers year 2013-2016 
SMEs also contribute to export receipts, although SME contributions are much smaller if it is compared with large business contributions. In 2005 the export value of small businesses reached 27,700 billion and created a role of 4.86 percent on total exports. Whereas in 2002 the same business scale export value of 20,496 billion and created a role of $5.13 \%$ on total exports. It means an increase in the value even though the export role in small businesses has decreased slightly. For medium enterprises, the export value also increased from 66.821 billion in $2002(16.74 \%)$ Increased to 81,429 billion with a reduced role of $14.30 \%$ in 2005 .

Based on the distribution of export revenues by business scale, the 2003-2005 period of the largest export drive sector in total is the processing industry, and the smallest export contributors are agriculture, livestock, forestry and fisheries sectors. Especially in small businesses, the largest contributor to non-oil exports is the processing industry sector followed by agriculture, livestock, forestry and fisheries sectors and lastly is the mining and excavation sector. As for medium enterprises, the largest contribution to exports is the processing industry sector [1].

The role of small Medium enterprises (SMEs) in Indonesia is very large and has been proven to save the nation's economy during the economic crisis in 1997. In the countries of the country, in the United States, Japan, Germany, Italy, SMEs are the main pillars of the country's economy. Besides, the SME development efforts by synergizing it with the big industry through partnership pattern will also strengthen the economic structure both national and regional. The participation of related parties or stakeholders should continue to be grown to develop so that SMEs are really able to do even greater in the national economy. Because of this basis in writing this researcher interested to take the title "Analysis of the influence of the SME industry to economic growth in Indonesia".

\subsection{Economic Growth}

Economic growth is a process of changing the economic condition of a sustainable country to better conditions during a certain period. According to Sukirno [2], Economic growth means the development of activities in the economy that causes goods and services produced in society increased and community prosperity increased. So that economic growth can also be interpreted as a process of increasing the production capacity of an economy that is realized in the form of national income increase. Economic growth is an indication of the success of economic development. The theory builds on the empirical experience, so the theory can serve as the basis for predicting and making policy. In general, theories of economic growth according to experts can be divided into two, namely the theory of historical economic growth and classical and neoclassical economic growth theory.

\subsection{Small Medium Enterprises}

Small and Medium Enterprises abbreviated UKM is a term that refers to the small business type that has the most net worth $\mathrm{Rp} 200$ million excluding land and building business. And a stand-alone endeavor. According to Presidential Decree No. 99 the year 1998, the sense of Small business is: "Small-scale economic activities with the business field which is mostly small business activities and need to be protected to prevent the business competition that Unhealthy.

Small business criteria according to LAW No. 9 year 1995 are as follows:

1. Having the most net worth Rp 200.000.000,-((two hundred million Rupiah) does not include land and business premises.

2. Have the most annual sales results Rp. 1 billion-(one billion Rupiah) 
3. Belongs to an Indonesian citizen

4. Stand-alone, not a subsidiary or branch company that is not owned, mastered, or affiliated either directly or indirectly with the medium enterprises or large enterprises

5. In the form of an individual business, a business entity that is not a legal entity, or a legal entity, including cooperatives.

According to the Ministry of Finance based on the decree of the Minister of Finance No. 316/KMK 016/1994 dated 27 June 1994 that small business as an individual/business entity that has been conducting activities/businesses that have sales/turnover per year highest Rp. 600 million or asset (assets) highest Rp. 600.000 .000 (outside land and occupied buildings). For example, firm, CV, PT, and cooperatives are in the form of a business entity. Meanwhile, examples in the form of individuals, such as household industry craftsmen, farmers, fishermen, goods, and services merchants.

\subsection{SME Exports}

Exports are the process of transporting goods or commodities from a country to another country. This process is often used by small to medium business enterprises as the main strategy to compete internationally. The export strategy is used due to lower risk. Capital is smaller and easier when compared to other strategies.

SME in Indonesia is very expected because it has great potential as one of the important sources of development (diversification) and growth of $\mathrm{X}$, specifically $\mathrm{X}$ manufacturing. The ability of Indonesian SMEs to realize its potential $\mathrm{X}$ is determined by a combination of a number of factors of relative excellence owned by Indonesian SMEs over its competitors, both in large enterprises (UB) and abroad.

Types of exports:

a. Direct export

Direct exports are a way of selling goods or services through intermediaries located in other countries or export destination countries. Sales are conducted through distributors and sales representatives of the company. The advantages are centralized production in the country of origin and control of better distribution. Its weakness, higher transportation costs for large-scale products and the presence of trade barriers and protectionism.

b. Indirect export

Indirect exports are techniques in which goods are sold through the intermediary of the country of origin then sold by the intermediary. Using this way, the of has a chance to... Through, export management company and exporting company (export trading companies). The excess, production resources are concentrated and do not need to handle exports directly. Its weakness, control of less distribution and knowledge of operations in other countries is lacking.

\section{Method Research}

\subsection{Research Approaches}

The research approach conducted in this study is associative/quantitative research as associative/quantitative research is a study aimed at knowing the degree of relationship and pattern/form of influence between two or more variables, wherewith this research it will be 
built a theory that serves to explain, predict and control a symptom [3]. This quantitative study presents the analysis of inferential statistical data with the path analysis model.

\subsection{Data analysis methods}

In this study the analysis method used is a descriptive and quantitative analysis as follows[6]:

1.) Descriptive analysis

In this case the author uses a descriptive statistical analysis technique. According to Sugiyono [4] that descriptive statistics are statistics used to analyze data by describing or depicting data that has been collected as it is without intent to make any conclusions that apply to Generalization. In this case, descriptive statistics know the development of SME units, labor and investment, and export SMEs and economic growth. Descriptive analysis is statistics used to analyze data by describing or describing data that has been collected as it is without intent to make conclusions that apply to public or generalization [3].

2.) Quantitative Analysis

According to Rusiadi [3], Associative/quantitative research is a study aimed at knowing the degree of relationship and pattern/form of influence between two or more variables, wherewith this research it will be built a theory that serves to explain, predict and control a symptom. According to Ghozali, track analysis is the development of a regression model that is used to test the suitability of a matrix correlation of two or more models compared. Path analysis was developed by Sewall Wright. Models are usually depicted with circles and arrows. The arrows show the relationship of causality. Regression analysis is done in every variable contained in the model. The regression value predicted by the model compared to the correlation matrix of variable observation results and the value of its goodness of Fitnya can be calculated. Based on the goodness of Fitnya, the best model can be determined. In constructing the pathway diagram, the relationship between the constructs is aimed at the line through one arrow indicating the relationship of causality or regression from the construct one with the other construct. A correlation or covariant relationship is indicated by a line through two arrows. There are two assumptions that lubricated from the line diagram, namely:

a. All causality relationships are based on theory. The theory is used as a basis or foundation in inserting and eliminating causality relationships

b. Causality relationship in linear diagram model.

The author uses the SPSS 16 computer program to process data. The models used in this analysis are econometrics models. The data analysis method used is the analysis path. The Model is as follows:

$$
\begin{aligned}
& \mathrm{Y}_{1}=\mathrm{f}\left(\mathrm{X}_{1}, \mathrm{X}_{2}, \mathrm{X}_{3}\right) \ldots \ldots \\
& \mathrm{Y}_{2}=\mathrm{f}\left(\mathrm{X}_{1}, \mathrm{X}_{2}, \mathrm{X}_{3}, \mathrm{Y}_{1}\right) .
\end{aligned}
$$

With the following model specifications:

$$
\begin{aligned}
& \mathrm{Y}_{1}=\alpha+\beta_{1} \mathrm{X}_{1}+\beta_{2} \mathrm{X}_{2}+\beta_{3} \mathrm{X}_{3}+\mu \ldots \ldots \ldots \ldots \ldots \\
& \mathrm{Y}_{2}=\alpha+\beta_{1} \mathrm{X}_{1}+\beta_{2} \mathrm{X}_{2}+\beta_{3} \mathrm{Y}_{1}+\beta_{3} \mathrm{X}_{3}+\beta_{4} \mathrm{Y}_{1}+\mu
\end{aligned}
$$




$\begin{array}{ll}\text { Where: } & \\ \mathrm{Y}_{2} & =\text { Economic growth (billion rupiahs) } \\ \mathrm{Y}_{1} & =\text { SME exports (Billion rupiah) } \\ \alpha & =\text { Intercept } \\ \beta_{1}, \beta_{2}, \beta_{3} & =\text { Regression coefficient } \\ \mathrm{X}_{1} & =\text { SME unit (million units) } \\ \mathrm{X}_{2} & =\text { Labour (million people) } \\ \mathrm{X}_{3} & =\text { Investment (Billion rupiah) } \\ \mu & =\text { Term of error }\end{array}$

\section{Results and Discussion}

\subsection{Test Data Normality}

Test data normality aims to test whether, in the regression model, the bully or residual variables have a normal distribution. To find out if any data has a normal distribution or not, the author uses graph analysis consisting of a histogram and a normal probability plot. The following is shown test normality by using the histogram chart and the normal probability plot.

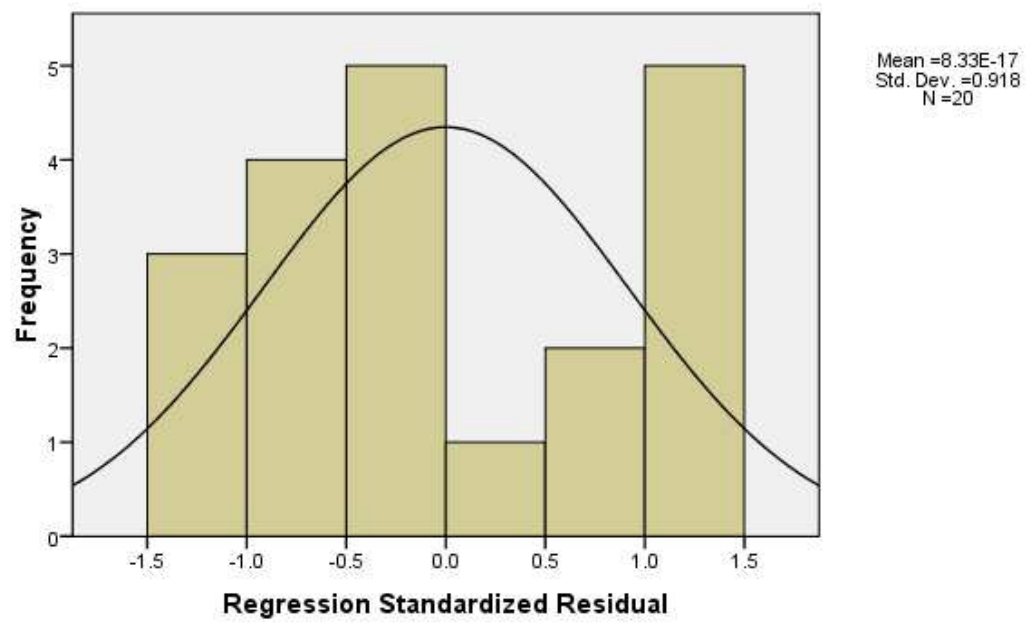

Fig 3. Test result normality with Histogram

The histogram line above indicates that the data has been distributed normally. It can be seen from the histogram chart indicating the distribution of data following the diagonal line indicating that the regression model meets the normality assumption. It is also supported with the normality test results using the Plot graph displayed in the following figure: 


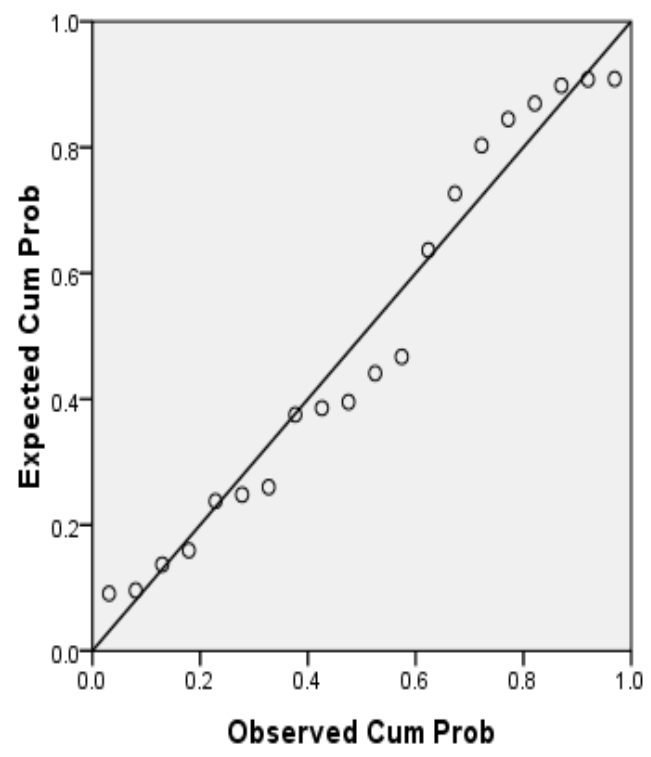

Fig 4. Test result normality with P-Plot

Based on the Normal P-Plot graph above, it can be seen that the dots spread diagonally (not scattered away from the diagonal line) then the Normal graph of P-Plot is declared normal so as to fulfill the assumption of normality.

\subsection{Multi co-linearity Tests}

Multi co-linearity tests are used to test whether or not a variable is free to have a perfect relationship. Multi co-linearity testing can be seen from the value of variance inflation factor (VIF) based on the output result SPSS, when the value of the VIF $<10$ and the value of Tolerance close to 1 can be concluded that the absence of multi co-linearity.

Table 2. Multi co-linearity test Results

\begin{tabular}{|c|c|c|c|c|c|c|}
\hline \multirow{2}{*}{\multicolumn{2}{|c|}{ Model }} & \multicolumn{3}{|c|}{ Correlations } & \multicolumn{2}{|c|}{ Co-linearity Statistics } \\
\hline & & Zero-order & Partial & Part & Tolerance & VIF \\
\hline \multirow[t]{5}{*}{1} & (Constant) & & & & & \\
\hline & SME Units & .608 & .599 & .526 & .940 & 1.064 \\
\hline & Labour & .885 & .543 & .314 & .900 & 1.455 \\
\hline & Investment & .474 & .453 & .357 & .944 & 1.060 \\
\hline & SME Exports & .004 & .164 & .117 & .975 & 1.026 \\
\hline
\end{tabular}

a. Dependent Variable: Economic Growth

Based on the table above can be concluded that the research is trouble-free multi colinearity. It can be seen by comparing the Tolerance and VIF values. From the results of this test, the Tolerance figures for all free variables are approaching number 1 indicating the absence of correlation between the free variables. And the value of VIF that shows the same 
thing is that it has a value smaller than 10 , so it can be concluded there is no multi co-linearity between variables free (independent).

\subsection{Interpretation of SME Unit on economic growth through SME export factors}

In order to prove that the export variable of SMEs can be an intervening variable between the SME units to economic growth, it will be calculated direct and indirect influence between the SME unit against economic growth. When the indirect influence of SME units to economic growth through SME exports is greater than the direct influence of SME units on the growth of fishermen's economy, the SME export factor can be an intervening variable between SME units To economic growth[7]. To perform the calculations directly and indirectly performed from the regression coefficients standardized each of the variables independent of the dependent variables. To know the influence of SME units through the export factor of SMEs to the economic growth used path analysis. The magnitude of the error value on each effect of the variable independent of the dependent in the can go through as follows:

$$
\begin{aligned}
& \mathrm{Pe}_{1}=\sqrt{1-0,971^{2}}=0,239 \\
& \mathrm{Pe}_{2}=\sqrt{1-0,838^{2}}=0,546
\end{aligned}
$$

In the trimming theory testing the validity of the research model was observed through the calculation of the total coefficient of determination as follows:

$$
\begin{aligned}
\mathrm{R}^{2} \mathrm{~m} & =1-\mathrm{P}^{2} \mathrm{e}_{1} \cdot \mathrm{P}^{2} \mathrm{e}_{2} \\
& =1-(0,239)^{2}(0,546)^{2} \\
& =1-(0,057)(0,298) \\
& =0,983 \\
& =98,3 \%
\end{aligned}
$$

The value of the coefficient of determination is $98.3 \%$, indicating that $98.3 \%$ of the information contained in the data can be explained by the model, while the remainder of $1.7 \%$ is explained by errors and other variables outside the model. The number of coefficients on this model is relatively large so it deserves further inner achievements. From the output of SPSS outputs provide a standardized beta value for SMEs units of 0.971 and significant at 0.000 that means the SME units affect the export of SMEs. The coefficient value Standardized beta 0.971 is the value of the path or path P2. In the following table SPSS output, the standardized beta value for SMB unit 0.442 and the SME export factor 0.636 are all significant. The value of the standardized SME units 0.422 is the path value of P1 and the value standardized beta $0.636 \mathrm{SME}$ export factor is the value of the P3 path. The magnitude of the value e1 $=(1-0,939) 2=0.00372$ and the magnitude of value E2 $=(1-0,663) 2=0.114$.

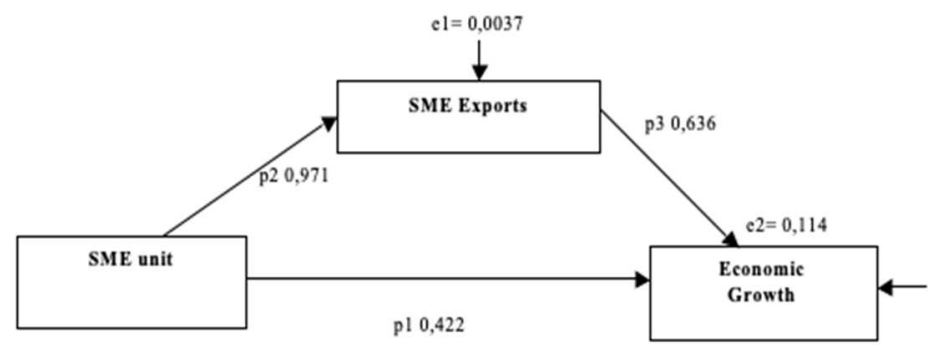

Fig 5. Intervening Analysis 
The result of the analysis of the pathway shows that the UKM unit can influence directly the economic growth and can also affect indirect is the SME unit to the export factor of SMEs (as intervening) and then to economic growth. The amount of direct influence is 0.442 whereas large indirect influence should be calculated by multiplying the indirect coefficient of $(0.971) \times(0.636)=0.618$ or the total influence of SME units to economic growth $=0.442+$ $(0.971 \times 0.636)=1.06$, by the value $(\mathrm{P} 2 \mathrm{X} \mathrm{P} 3>\mathrm{P} 1)$ then the SME export factor serves as a intervening variable [8].

The results of the calculations showed indirect influence through the SME's export factor is greater than the direct influence on economic growth. These results show that UKM units have an effect on economic growth through the SME's export factor as an intervening variable, or it can be concluded that the SME's export factor becomes an intervening variable between the SME unit to economic growth. Based on this, the research hypothesis stating that UKM units are influential for economic growth through the export of SMEs received empirical support or can be deduced accepted hypotheses.

\subsection{Interpretation of labor on economic growth through SME export factors}

In order to prove that the export variable of SMEs is able to intervening between workers to economic growth, it will be calculated direct and indirect influence between labor to economic growth. If the influence of indirect labor on economic growth through the SME exports is greater than the direct influence of labor on economic growth, then the SME export factor can be the intervening variable between energy Work against economic growth. To perform the calculations directly and indirectly performed from the regression coefficients standardized each of the variables independent of the dependent variables [9]. To know the influence of labor through the export factor of SMEs to the economic growth used path analysis. The magnitude of the error value on each effect of the variable independent of the dependent in the can through the following calculations:

$$
\begin{aligned}
& \mathrm{Pe}_{1}=\sqrt{1-0,895^{2}}=0,446 \\
& \mathrm{Pe}_{2}=\sqrt{1-0,970^{2}}=0,243
\end{aligned}
$$

In the trimming theory testing the validity of the research model was observed through the calculation of the total coefficient of determination as follows:

$$
\begin{aligned}
\mathrm{R}^{2} \mathrm{~m} & =1-\mathrm{P}^{2} \mathrm{e}_{1} \cdot \mathrm{P}^{2} \mathrm{e}_{2} \\
& =1-(0,446)^{2}(0,243)^{2} \\
& =1-(0,199)(0,060) \\
& =1-0,012 \\
& =98,8 \%
\end{aligned}
$$

The value of the coefficient of determination is $98.8 \%$, indicating that $98.8 \%$ of the information contained in the data can be explained by the model, while the remainder of $1.2 \%$ is explained by errors and other variables outside the model. The number of coefficients on this model is relatively large so it deserves further inner achievements. From the output of SPSS outputs provide a standardized beta value for the workforce of 0.895 and significant at 0.000 that means the workforce affects SME exports. The coefficient value Standardized beta 0.895 is the value of the path or path P2. In the following table SPSS output, the standardized 
beta value for Labor 0.340 and the SME export factor 0.435 are all significant. The standardized beta value of the workforce 0340 is the value of path P1 and the standardized value beta of the SME export factor 0435 is the $\mathrm{P} 3$ path value. The magnitude of the value of $\mathrm{e} 1=(1-0,789) 2=0.045$, and the magnitude of value E2 $=(1-0,933) 2=0.0045$.

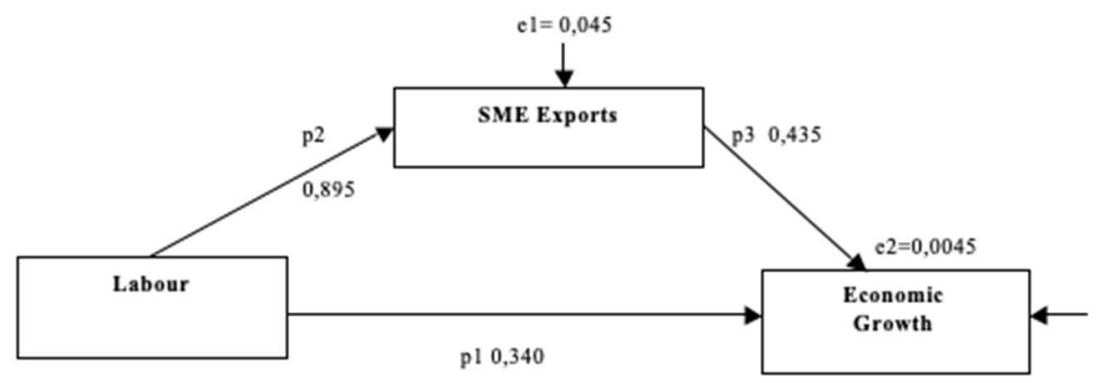

Fig 6. Intervening Analysis

The result of the analysis of the pathway shows that the workforce can affect directly into economic growth and can also influence the SME unit to the export factor of SMEs (as intervening) and then to economic growth. The amount of direct influence is 0.340 whereas the big indirect influence should be calculated by multiplying the indirect coefficient is $(0.895) \times(0.435)=0.390$, or total labor influence to economic growth $=0.340+(0.895 \times$ $0.435)=0.73$. Because the value $(\mathrm{P} 2 \mathrm{X} \mathrm{P} 3>\mathrm{P} 1)$ then the SME export factor serves as an intervening variable.

The results of the calculations showed indirect influence through the SME's export factor is greater than the direct influence on economic growth. These results indicate that the workforce affects the growth of fishermen through the export factor of SMEs as an intervening variable, or it can be concluded that the SME export factor into the intervening variable between labor and Economic growth. Based on that, the research hypothesis that states that the workforce affects economic growth through the export of SMEs gets empirical support or can be deduced accepted hypotheses.

\subsection{Interpretation Investments in economic growth through SME export factors}

In order to prove that the export variable of SMEs can be an intervening variable between investments to economic growth, it will be calculated direct and indirect influence between investments to economic growth [10]. When the indirect influence of investment on economic growth through the SME exports is greater than the direct investment influence on economic growth, the SME export factor can be the intervening variable between investments To economic growth. To perform the calculations directly and indirectly performed from the regression coefficients standardized each of the variables independent of the dependent variables. To know the influence of investment through the export factor of SMEs to the economic growth used path analysis. The magnitude of the error value on each effect of the variable independent of the dependent in the can through the following calculations:

$$
\begin{aligned}
& \mathrm{Pe}_{1}=\sqrt{1-\overline{0,884^{2}}=} 0,468 \\
& \mathrm{Pe}_{2}=\sqrt{1-0,930^{2}=} 0,606
\end{aligned}
$$


In the trimming theory testing the validity of the research model was observed through the calculation of the total coefficient of determination as follows:

$$
\begin{aligned}
\mathrm{R}^{2} \mathrm{~m} & =1-\mathrm{P}^{2} \mathrm{e}_{1} \cdot \mathrm{P}^{2} \mathrm{e}_{2} \\
& =1-(0,468)^{2}(0,606)^{2} \\
& =1-(0,219)(0,367) \\
& =0,92 \\
& =92 \%
\end{aligned}
$$

The value of the coefficient of determination is $92 \%$, indicating that $92 \%$ of the information contained in the data can be explained by the model, while the remaining $8 \%$ is explained by errors and other variables outside the model. The number of coefficients on this model is relatively large so it deserves further inner achievements. From the output of SPSS outputs provide standardized beta value for investments amounting to 0.884 and significant at 0.000 that means investments affect the export of SMEs. The coefficient value Standardized beta 0884 is the value of the path or path P2. In the following table SPSS output, the standardized beta value for investment 0.134 and the SME export factor 0.238 are all significant. The standardized value of investment beta 0134 is the path value of P1 and the value standardized beta export factor SME 0.238 is the value of the P3 path. The magnitude of the value $1=(1-0.768) 2=0.054$ and the magnitude of value E2 $=(1-0.847) 2=0.023$.

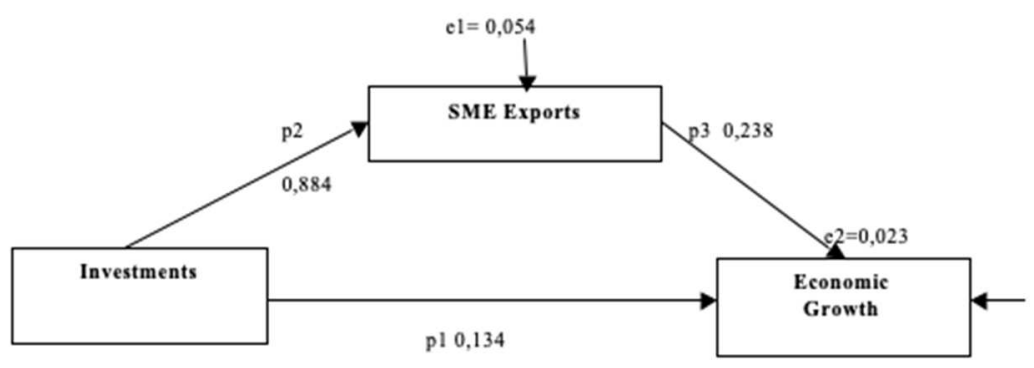

Fig 7. Intervening Analysis

The results of the track analysis show that investments can affect directly to economic growth and can also affect indirect is the SME unit to the export factor of SMEs (as intervening) and then to economic growth. The amount of direct influence is 0.134 whereas the big indirect influence should be calculated by multiplying the indirect coefficient of $(0.884) \times(0.238)=0.210$, or total investment influence to economic growth $=0.134+(0.884$ $\mathrm{x} 0.238)=0.344$. Because the value $(\mathrm{P} 2 \mathrm{X} \mathrm{P} 3>\mathrm{P} 1)$ then the SME export factor serves as an intervening variable.

The results of the calculations showed indirect influence through the SME's export factor is greater than the direct influence on economic growth. These results show that the investment affects the economic growth through the SME export factor as an intervening variable, or it can be concluded that the SME export factor into an intervening variable between investments to growth Economic. Based on that, the research hypothesis that states that investment affects economic growth through the export of SMEs get empirical support or can be deduced accepted hypotheses. 


\section{Conclusions and Recommendation}

\subsection{Conclusion}

Based on the research conducted in the role of SME industry to economic growth in Indonesia, it can be concluded as follows:

1) There are results indicating that the UKM unit has a significant effect on economic growth through the SME export factor as an intervening variable, or it can be concluded that the SME export factor into an intervening variable between the SME unit against Economic growth in Indonesia.

2) There are results indicating that the number of workers has a significant effect on economic growth through the SME export factor as an intervening variable, or it can be concluded that the SME export factor into an intervening variable between The number of workers in economic growth in Indonesia.

3) There are results showing that the investment has a significant effect on economic growth through the SME export factor as an intervening variable, or it can be concluded that the SME export factor into an intervening variable between investments to economic growth in Indonesia.

\subsection{Recommendation}

The suggestions given by the authors are:

1) The Government should consider the SME sector before making a decision to determine the economic policy. This factor is strategically influential in addressing the problems of unemployment and economic growth. By increasing the role of the SME sector through training and funding assistance can improve the welfare of the community in particular and the economic growth of Indonesia in general.

2) The limitations of other factors used as a basis to predict economic growth in Indonesia through the role of SMEs that are limited to the number of SMEs units, the number of workers, investments, and exports of SMEs. It is expected in subsequent studies to pay attention to the influence of other factors that can affect economic growth from other SME's angles.

3) As time goes on and enters the modernization world, the SME sector is required to compete globally to increase its contribution to Indonesian GDP. So that the Government should perform more effective empowerment to improve the competitiveness of the SME sector. Because the government is one of the containers that can bridge the SME sector because considering the greater export opportunities in the SME sector and can compete in the international world later.

4) Improvement of manpower skills or human resources should also be more concerned in order to obtain quality products that have high value as well as high competitiveness as well. With such, it will also help reduce existing unemployment so as to improve welfare in the SME field. 


\section{References}

[1] DEPKOP. Data Usaha Mikro Kecil dan Menengah tahun 1999-2016. Departemen Koperasi, dari http://www.depkop.go.id. (2017)

[2] Sukirno, Sadono. Pengantar Teori Mikroekonomi. Jakarta: Raja Grafindo Persada. (2002).

[3] Rusiadi, dkk. Metode Penelitian, Manajemen Akuntasi dan Ekonomi Pembangunan, Konsep, Kasus dan Aplikasi SPSS, Eviews, Amos, Lisrel. Medan: USU Press. (2013).

[4] Sugiyono. Metode penelitian Kuantitatif Kualitatif dan $R \& D$. Bandung : Alfabeta. (2010).

[5] Arfida. Ekonomi Sumber Daya Manusia. Jakarta: Ghalia Indonesia. (2003).

[6] Hidayat. Menyusun skripsi dan Tesis. Bandung: Informatika Bandung. (2010).

[7] Arsyad, Lincolin. Ekonomi Manajerial, Ekonomi Mikro Terapan untuk Manajemen Bisnis. Yogyakarta: BPFE. (2000).

[8] Dewanti, Retno. Kewirausahaan. Jakarta: Mitra Wacana Media. (2008).

[9] Fauzi, Muchammad. Metode Penelitian Kuantitatif. Semarang: Walisongo Press. (2009).

[10] Kasmir. Kewirausahaan. Jakarta: PT. Raja Grafindo Persada. (2006). 